\title{
EFISIENSI PENGGUNAAN FAKTOR-FAKTOR PRODUKSI DALAM PRODUKSI JAHE GAJAH
}

\author{
(Studi Kasus Gapoktan Sarwa Ada Desa Taro Kecamatan Tegallalang \\ Kabupaten Gianyar) \\ Efficiency in Using Factors of Production in Jahe Gajah Production \\ (Case Study of Sarwa Ada Gapoktan in Taro Village, Tegallalang District, Gianyar Regency) \\ Bagus Ade Tegar Prabawa, Ratna Komala Dewi
}

Program Studi Magister Agribisnis, Fakultas Pertanian, Universitas Udayana, Bali, Indonesia

Email: tegarprabawa@ymail.com

\begin{abstract}
ABSTRACK
The maximum production can be achieved if using optimum inputs. Production efficiency is influenced by the use of production inputs. The purpose of this research was to examin: the effect of production factors of jahe gajah; inefficiency and efficiency factor of jahe gajah; farmer's income in jahe gajah farming; and constraints faced in Jahe Gajah production. The research method uses quantitative descriptive methods. The number of samples in this is researc were 66 people determined by the Simple Random Sampling technique. Production efficiency was analyzed using the Stochastic Frontier production function with the Frontier 4.1c program and farmer's income was analyzed using $R / C$ ratio. The results of the research indicate that: land area variables affect production; education, experience, counseling dummy variables influence production, while jahe gajah farm is stated to be technically efficient with an average value of 0.910 , but not yet allocatively efficient with an average value of 0.668 and not economically efficient with average values of 0.599; the jahe gajah farm has profit $R / C$ ratio 1,7; constraints faced by jahe gajah farmers there is no standards price, difficulty in obtaining market access, and rhizome rotten disease.
\end{abstract}

Keywords: Efficiency, Factors of Production, Income, Jahe Gajah

\begin{abstract}
ABSTRAK
Produksi yang maksimum dapat dicapai apabila penggunaan input secara optimum. Efisiensi produksi dipengaruhi oleh penggunaan input produksi. Tujuan penelitian ini adalah untuk mengkaji; (1) pengaruh faktor-faktor produksi jahe gajah; (2) faktor inefisiensi dan efisiensi produksi jahe gajah; (3) pendapatan petani dalam usaha tani jahe gajah; dan (4) Kendala-kendala yang dihadapi dalam produksi jahe gajah. Metode penelitian menggunakan metode deskriptif kuantitatif. Jumlah sampel dalam penelitian ini sebanyak 66 orang ditentukan dengan teknik Simple Random Samplin. Efisiensi produksi dianalisis menggunakan fungsi produksi Stochastic Frontier dengan program Frontier 4.1c dan pendapatan petani dianalisis menggunakan $\mathrm{R} / \mathrm{C}$ ratio. Hasil penelitian menunjukkan bahwa; (1) variabel luas lahan berpengaruh nyata terhadap produksi; (2) variabel pendidikan, pengalaman dan dummy penyuluhan berpengaruh nyata terhadap produksi, sedangkan usaha tani jahe gajah dinyatakan efisien secara teknis dengan nilai rata-rata sebesar 0,910, namun belum efisien secara alokatif dengan nilai rata-rata sebesar 0,668 dan belum efisien secara ekonomis dengan nilai rata-rata sebesar 0,599; (3) usaha tani jahe gajah sudah mengalami keuntungan dengan nilai R/C ratio sebesar 1,7; (4) kendala yang dihadapi petani jahe gajah adalah belum adanya standar harga, sulitnya mendapat akses pasar, dan penyakit busuk rimpang.
\end{abstract}

Kata kunci: Efisiensi, Faktor-faktor Produksi, Pendapatan, Jahe Gajah

\section{PENDAHULUAN}

\section{Latar Belakang}

Sub sektor perkebunan merupakan salah satu sub sektor dari sektor pertanian yang dapat meningkatkan devisa negara dan menyerap tenaga kerja. Pemerintah mengutamakan pada subsektor perkebunan, karena memiliki daya tarik yang tinggi untuk diekspor ke negara maju. Komoditas yang termasuk komoditas sub sekor perkebunan yang memiliki prospek pengembangan yang baik adalah tanaman jahe (Zingiber Oflnule). Data Kementerian Perdagangan Republik Indonesia menunjukkan volume ekspor jahe dari tahun ke tahun mengalami peningkatan. Selama periode tahun 2010 - 2015, rata-rata volume ekspor jahe 
mengalami peningkatan $7,55 \%$ per tahun (Depag, 2016). Budidaya jahe Indonesia tersebar di 34 provinsi dengan pertumbuhan produksi jahe tahun 2014-2015 sebesar 5.22\%. Pada tahun 2015 pertumbuhan produksi Provinsi Bali sebesar $197,47 \%$, merupakan pertumbuhan tertinggi di Indonesia pada tahun 2014-2015. Badan Pusat Statistik Provinsi Bali menunjukkan produksi jahe di Bali tahun 2015 adalah $5.735 .658 \mathrm{~kg}$, dimana Kabupaten Gianyar berkontribusi sebesar 51,36\% dari total produksi di Bali. Produksi terbesar kedua adalah Kabupaten Karangasem, yaitu $1.056 .342 \mathrm{~kg}$ atau $18,41 \%$ dan sisanya tersebar di Kabupaten Badung, Bangli, dan Jembrana

Kabupaten Tabanan, Klungkung, Buleleng, dan Denpasar tidak memproduksi jahe dikarenakan agroklimat daerah tersebut tidak sesuai untuk budidaya jahe. Produksi jahe di Kabupaten Gianyar dari tahun 2012-2015 cenderung berfluktuasi. Penurunan jumlah produksi jahe dari tahun 2012-2014 disebabkan oleh; (1) pengurangan luas lahan akibat peralihan lahan yang semula ditanami tanaman jahe diganti dengan tanaman pangan, (2) serangan hama dan penyakit sehingga menyebabkan produksi jahe rendah, (3) penggunaan input produksi yang belum optimal, dan (4) nilai jual jahe rendah sehingga petani enggan untuk menanam.

Salah satu kawasan budidaya jahe di Kecamatan Tegallalang yaitu di Gapoktan Sarwa Ada Desa Taro, Kecamatan Tegallalang, Kabupaten Gianyar. Berdasarkan hasil wawancara dengan ketua Gapoktan Sarwa Ada, jenis jahe yang dibudidayakan di Desa Taro adalah jahe gajah, jahe merah, dan jahe putih kecil. Namun dua tahun terakhir petani di Desa Taro cenderung menanam jahe gajah karena jahe gajah lebih tahan penyakit dan harga jual jahe gajah lebih tinggi. Permintaan terhadap jahe gajah di Gapoktan Sarwa Ada terus mengalami peningkatan akan tetapi tidak diimbangi dengan peningkatan produksi.

Menurut Soekartawi (2005), dalam meningkatkan hasil produksi pertanian dan pertumbuhan tanaman yang baik perlu memperhatikan penggunaan faktor produksi, seperti pemilihan bibit unggul, penggunaan lahan secara optimal, pemberian pupuk secara tepat baik tepat waktu maupun tepat jumlah dan penggunaan tenaga kerja yang efisien. Usaha tani dapat dikatakan berhasil apabila faktorfaktor produksi dipergunakan secara efisien untuk mencapai hasil yang maksimal dalam berusaha tani.

Efisiensi produksi dapat mempengaruhi tingkat produksi yang dihasilkan dengan menunjukkan seberapa besar output dapat dihasilkan dari kombinasi input yang tersedia. Petani dapat dikatakan efisien apabila petani menggunakan kombinasi input yang sama kemudian menghasilkan output yang lebih banyak atau petani mampu menghasilkan output dengan kuantitas yang sama tetapi menggunaan input yang lebih sedikit. Jika penggunaan faktor-faktor produksi berdampak positif terhadap efisiensi maka akan terjadi peningkatan efisiensi. Efisiensi sangat erat kaitannya dengan pendapatan. Jika efisiensi semakin tinggi maka pendapatan yang diperoleh petani akan semakin maksimal.

Upaya petani jahe gajah di Gapoktan Sarwa Ada dalam mencapai pendapatan yang maksimal dihadapkan pada beberapa kendala, yaitu kendala biologis maupun kendala sosial ekonomi. Kendala teknis meliputi penggunaan faktor-faktor produksi dalam usaha tani jahe yang belum optimal seperti penggunaan jumlah bibit, penggunaan pupuk, penggunaan tenaga kerja, serangan hama penyakit, iklim, tekik budidaya, dan sebagainya. Kendala ekonomis meliputi besarnya biaya produksi, harga jual jahe gajah yang tidak menentu, dan sebagainya.

Oleh sebab itu, perlu dilakukan penelitian tentang "Efisiensi Produksi Penggunaan Faktor-Faktor Produksi Dalam Produksi Jahe Gajah di Gapoktan Sarwa Ada Desa Taro, Kecamatan Tegallalang, Kabupaten Gianyar". Hal ini dimaksudkan untuk memberikan pandangan baru pada petani jahe gajah dalam menggunakan faktor-faktor produksi agar memperoleh hasil produksi yang maksimal.

\section{Tujuan Penelitian}

Penelitian ini bertujuan untuk mengkaji pengaruh faktor-faktor produksi jahe gajah, mengkaji faktor inefisiensi dan efisiensi, mengkaji pendapatan petani, dan mengkaji kendala-kendala yang dihadapi dalam produksi jahe gajah di Gapoktan Sarwa Ada Desa Taro, Kecamatan Tegallalang, Kabupaten Gianyar.

\section{Hipotesis}

Adapun hipotesis pada penelitian ini adalah sebagai berikut:

1.Faktor-faktor produksi berpengaruh terhadap hasil produksi jahe gajah di Gapoktan Sarwa Ada Desa Taro Kecamatan Tegallalang, Kabupaten Gianyar.

2.Penggunaan input produksi jahe gajah di Gapoktan Sarwa Ada Desa Taro Kecamatan Tegallalang, Kabupaten Gianyar dinyatakan efisien secara teknis.

3.Penggunaan input produksi jahe gajah di Gapoktan Sarwa Ada Desa Taro Kecamatan Tegallalang, Kabupaten Gianyar dinyatakan efisien secara alokatif.

4.Penggunaan input produksi jahe gajah di Gapoktan Sarwa Ada Desa Taro Kecamatan Tegallalang, Kabupaten Gianyar dinyatakan efisien secara ekonomis.

\section{METODE PENELITIAN}

\section{Lokasi dan Waktu Penelitian}

Lokasi penelitian dilaksanakan di Gapoktan Sarwa Ada Desa Taro Kecamatan Tegallalang, 
Kabupaten Gianyar. Penentuan lokasi ini dilakukan secara sengaja (purposive) atas dasar pertimbangan-pertimbangan sebagai berikut (1) Kabupaten Gianyar merupakan penghasil jahe tertinggi di Bali, (2) produksi jahe di Kabupaten Gianyar pada tahun 2015 sebesar 72,8\% dihasilkan di Kecamatan Tegallalang, (3) Desa Taro merupakan salah satu sentra jahe yang ada di Kecamatan Tegallalang. Penelitian dilaksanakan pada Bulan April s.d. Mei 2018 dengan asumsi pada rentang bulan tersebut keseluruhan dari lahan jahe gajah yang terkoordinasi di bawah Gapoktan Sarwa Ada Desa Taro sedang dalam persiapan masa panen.

\section{Jenis dan Bentuk Data}

Jenis data yang dikumpulkan dalam penelitian ini adalah data kualititif dan data kuantitatif. Data kuantitatif dikumpulkan yaitu, pada luas lahan, penggunaan jumlah bibit, jumlah penggunaan pupuk kandang, pupuk urea, pupuk SP-36, pupuk KCL dan jumlah tenaga kerja, biaya produksi, harga jual, pendapatan satu sikluas tanam, dan sebagainya. Data kualitatif dikumpulkan seperti gambaran umum daerah penelitian, kendalakendala yang dihadapi dalam usaha tani jahe gajah, dan sebagainya. Sumber data yang dikumpulkan berasal dari sumber primer dan sumber sekunder. Sumber primer yaitu data yang dikumpulkan langsung dilapangan dengan melakukan wawancara dengan petani (sumber primer) dengan menggunakan daftar pertanyaan atau kuesioner terstruktur (Sugiyono, 2014). Jenis dan sumber data sekunder diperoleh secara tidak langsung dari objek penelitian (Sugiyono, 2014).

\section{Metode Pengumpulan Data}

Data yang dikumpulkan dalam penelitian ini dilakukan dengan menggunakan metode sebagai berikut (1) wawancara (Interview), (2) studi pustaka, (3) observasi.

\section{Populasi dan Sampel Penelitian}

Menurut Mantra dan Kasto (1982), populasi adalah keseluruhan unit analisis yang ciri-cirinya akan diduga, sedangkan sampel merupakan cuplikan atau bagian kecil yang ditarik dari populasi. Populasi dalam penelitian ini adalah seluruh petani jahe gajah yang ada di Gapoktan Sarwa Ada Desa Taro Kecamatan Tegallalang, Kabupaten Gianyar yaitu sebanyak 187 petani. Penentuan sampel anggota gapoktan menggunakan pendekatan Slovin maka jumlah sampel yang diperoleh adalah sebesar $\mathrm{n}=65,15$ dibulatkan menjadi 66 orang.

\section{Variabel Penelitian}

Variabel, indikator, dan pengukuran efisiensi produksi penggunaan faktor-faktor produksi dalam Produksi jahe gajah di Gapoktan Sarwa Ada.
Tabel 1. Variabel, Indikator, dan Pengukuran Penelitian

\begin{tabular}{|c|c|c|}
\hline Variabel & Indikator & Pengukuran \\
\hline $\begin{array}{l}\text { Faktor } \\
\text { Produksi }\end{array}$ & $\begin{array}{l}\text { Luas Lahan }\left(\mathrm{X}_{1}\right) \\
\text { Jumlah Bibit }\left(\mathrm{X}_{2}\right) \\
\text { Jumlah Pupuk } \\
\text { Kandang }\left(\mathrm{X}_{3}\right) \\
\text { Jumlah Pupuk } \\
\text { Urea }\left(\mathrm{X}_{4}\right) \\
\text { Jumlah Pupuk SP- } \\
36\left(\mathrm{X}_{5}\right) \\
\text { Jumlah Pupuk } \\
\text { KCL }\left(\mathrm{X}_{6}\right) \\
\text { Tenaga Kerja }\left(\mathrm{X}_{7}\right)\end{array}$ & Kuantitatif \\
\hline $\begin{array}{l}\text { Faktor } \\
\text { Inefisiensi }\end{array}$ & $\begin{array}{l}\text { Umur }\left(\mathrm{Z}_{1}\right) \\
\text { Tingkat } \\
\text { Pendidikan }\left(\mathrm{Z}_{2}\right) \\
\text { Pengalaman } \\
\text { Usaha tani }\left(\mathrm{Z}_{3}\right) \\
\text { Dummy } \\
\text { Penyuluhan }\left(\mathrm{Z}_{4}\right)\end{array}$ & Kuantitatif \\
\hline $\begin{array}{l}\text { Efisiensi } \\
\text { Produksi }\end{array}$ & $\begin{array}{l}\text { Efisiensi Teknis } \\
\text { Efisiensi Harga } \\
\text { Efisiensi } \\
\text { Ekonomis }\end{array}$ & Kuantitatif \\
\hline $\begin{array}{l}\text { Kendala- } \\
\text { kendala }\end{array}$ & $\begin{array}{l}\text { Kendala Teknis } \\
\text { dan Ekonomis }\end{array}$ & Kualitatif \\
\hline
\end{tabular}

\section{Metode Analisis}

Dalam mengukur faktor-faktor produksi dipergunakan metode analisis model stochastic frontier merupakan perluasan dari model asli deterministik untuk mengukur efek-efek yang tak terduga (stochastic effects) di dalam batas produksi. Model fungsi produksi stochastic frontier dinyatakan sebagai berikut.

Ln $Y=\beta_{0}+\beta_{1} \ln X_{1}+\beta_{2} \ln X_{2}+\beta_{3} \ln X_{3}+\beta_{4} \ln X_{4}+$ $\beta_{5} \ln X_{5}+\beta_{6} \ln X_{6}+\beta_{7} \ln X_{7}+$ vi - ui

\section{dimana:}

Y : produksi jahe gajah $(\mathrm{kg})$

$\mathrm{X}_{1} \quad$ : luas lahan yang digarap (ha)

$\mathrm{X}_{2} \quad$ : jumlah benih yang digunakan $(\mathrm{kg})$

$\mathrm{X}_{3} \quad$ : jumlah pupuk kandang yang digunakan $(\mathrm{kg})$

$\mathrm{X}_{4} \quad$ : jumlah pupuk urea yang digunakan

(kg)

$\mathrm{X}_{5} \quad$ :jumlah pupuk SP-36 yang digunakan

(kg)

$\mathrm{X}_{6} \quad$ :jumlah pupuk KCL yang digunakan

(kg)

$\mathrm{X}_{7} \quad$ : jumlah tenaga kerja yang digunakan petani (HOK)

$\beta_{0}$ : Intersep 
$\beta_{j}$ : koefisien parameter penduga dimana $i=$ $1,2,3, \ldots$

$v_{i}-u_{\mathrm{i}} \quad$ : error term $\left(u_{i}\right)$ efek inefisiensi teknis dalam model.

Variabel $u_{i}$ yang digunakan untuk mengukur efek inefisiensi, diasumsikan bebas dan distribusinya terpotong normal dengan:

$N\left(\mu_{i}, \sigma^{2}\right)$.

Untuk menentukan nilai parameter distribusi $\left(\mu_{i}\right)$ efek inefisiensi pada penelitian ini digunakan rumus sebagai berikut.

$\mu_{i}=\delta_{0}+\delta_{1} Z_{1}+\delta_{2} Z_{2}+\delta_{3} Z_{3}+\delta_{4} Z_{4}+w_{i t}$

dimana:

$U$ i: efek inefisiensi teknis

$\delta 0$ : konstanta

$\mathrm{Z}_{1}$ : umur petani (tahun)

$\mathrm{Z}_{2}$ : tingkat pendidikan petani (tahun)

$\mathrm{Z}_{3}$ : pengalaman usaha tani jahe gajah (tahun)

$\mathrm{Z}_{4}$ : dummy penyuluhan (1: pernah mengikuti penyuluhan dan 0 tidak pernah mengikuti)

wit: error term

Nilai koefisien yang diharapkan adalah : $\delta 1, \delta 2$, $\delta 3, \delta 4,<0$

Untuk mengukur efisiensi teknis menurut Soekartawi (2001), dapat dihitung dengan rumus sebagai berikut.

$T E=i Y / i \hat{Y}$

dimana :

$T E$ : tingkat efisiensi teknis

i $Y$ : besarnya produksi (output) ke-i

$i \hat{Y}$ : besarnya produksi yang diduga pada pengamatan ke-i yang diperoleh melalui fungsi produksi frontier.

Menurut Nicholson (2002), efisiensi harga tercapai apabila perbandingan antara nilai produktivitas marginal masing-masing input (NPMxi) dengan harga inputnya (vi) atau ki $=1$. Kondisi ini menghendaki NPMx sama dengan harga faktor produksi $\mathrm{X}$ atau dapat ditulis sebagai berikut:

Efisiensi alokatif $=\frac{\text { nilai produk marginal }}{\text { harga input }}$

$$
\begin{aligned}
& =\frac{N P M x i}{P x i}=1 \\
\text { NPMxi } & =\text { PMxi } \cdot \text { Py } \\
& =\text { bi } \cdot \frac{Y}{X i} \cdot P y
\end{aligned}
$$

dimana;

PMxi : Produk marginal faktor produksi ke-i

bi : Koefisien regresi xi xi : Rata-rata penggunaan faktor produksi jahe ke-i

Pxi : Rata-rata harga faktor produksi jahe ke-i

Py : rata-rata harga satuan hasil produksi jahe

Efisiensi ekonomi dapat dicapai jika efisiensi teknis dan alokatif tercapai sehingga dapat dituliskan sebagai berikut:

$$
\mathrm{AE}=\frac{T E}{E E} ; \text { dengan } 0 \leq \mathrm{EE} \leq 1
$$

dimana:

\section{EE : Efisiensi Ekonomi \\ TE : Efisiensi Teknis}

$\mathrm{AE}$ : Efisiensi Alokatif

Analisis pendapatan usaha tani digunakan rumus sebagai berikut.

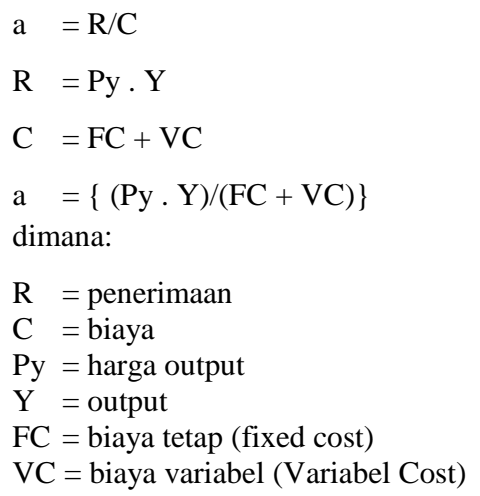

\section{HASIL DAN PEMBAHASAN}

Faktor-fakator yang mempengaruhi produksi jahe gajah

Hasil pendugaan dengan metode maksimum likelihood estimate (MLE) menggambarkan bahwa seluruh variabel menghasilkan koefisien positif. Pendugaan fungsi produksi jahe gajah dengan metode MLE di Gapoktan Sarwa Ada Desa Taro, Kecamatan Tegallalang, Kabupaten Gianyar tahun 2018 dapat dilihat pada Tabel 2.

Tabel 2. Hasil Pendugaan Fungsi Produksi Jahe

\begin{tabular}{lccc}
\hline Variabel & Koefisien & $\begin{array}{c}\text { Standard } \\
\text { error }\end{array}$ & t-ratio \\
\hline $\begin{array}{l}\text { Konstanta } \\
\text { Luas lahan }\end{array}$ & 5,095 & 0,47722 & 10,67561 \\
& 0,408 & 0,10861 & $3,76006^{* * *}$ \\
Bibit & 0,142 & 0,11828 & 1,20106 \\
Pupuk & 0,025 & 0,84314 & 0,30232 \\
kandang & & & \\
Urea & 0,117 & 0,12887 & 0,91100 \\
SP-36 & 0,023 & 0,05081 & 0,45473 \\
KCL & 0,069 & 0,06701 & 0,06701 \\
Tenaga & 0,155 & 0,09416 & 0,09416 \\
kerja & & & \\
\hline
\end{tabular}


Keterangan:

* = berpengaruh nyata pada taraf $\alpha 10 \% \quad(1,668)$

** = berpengaruh nyata pada taraf $\alpha 5 \%(1,997)$

$* * *=$ berpengaruh nyata pada taraf $\alpha 1 \%(2,654)$

\section{Luas lahan}

Pada Tabel 2 dapat diketahui bahwa variabel luas lahan mempunyai koefisien sebesar 0,408 dengan nilai $t_{\text {hitung }} 3,760$, dengan ini berarti nilai $t_{\text {hitung }}$ lebih besar dengan nilai $t_{\text {tabel }}$ yaitu 2,654. Memiliki nilai koefisien positif berarti variabel luas lahan berpengaruh nyata terhadap produksi jahe gajah. Variabel luas lahan diperoleh nilai koefisiennya sebesar 0,408. Angka ini menunjukkan bahwa penambahan input luas lahan sebesar 1\% (dimana input lainnya tetap), maka akan meningkatkan produksi jahe gajah dengan tambahan produksi sebesar $0,408 \%$. Hal ini sejalan dengan hasil penelitian yang menyatakan bahwa input luas lahan berpengaruh terhadap produksi (Lama, 2016; Fallo, 2018; Purnami, 2012; Misgiantoro, 2017).

Implikasinya adalah jika petani ingin meningkatkan produksi jahe gajah, maka luas lahan yang diusahakan petani harus ditingkatkan atau melakukan usaha tani jahe gajah pada satu areal tanam dengan pola monokultur. Fakta yang terjadi di lapangan petani jahe gajah selain mengusahakan komoditas jahe gajah sebagai komoditas utama, juga mengusahakan komoditas tanaman lainya seperti cabai dan jeruk dengan pola tumpangsari. Hal ini diduga bahwa produksi jahe gajah yang selama ini menurun disebabkan karena padatnya jumlah tanaman yang diusahakan dalam satu areal lahan. Selain itu kepadatan tanaman dalam satu areal lahan diduga juga menyebabkan tanaman jahe gajah terserang hama dan penyakit seperti penyakit busuk rimpang karena tingginya kelembaban udara.

\section{Bibit}

Variabel bibit mempunyai koefisien sebesar 0,142 dengan nilai $t_{\text {hitung }}$ sebesar 1,201 . Nilai $t_{\text {hitung }}$ lebih kecil dari $t_{\text {tabel }}$ pada taraf $10 \%(1,668)$, dengan demikian variabe bibit berpengaruh tidak nyata terhadap produksi. Menurut Soekartawi et al, 1986 menjelaskan bahwa bibit merupakan cikal bakal terhadap hasil produksi tanaman sehingga jika bibit yang diunakan adalaha bibit unggul dan bersertifikat maka hasil produksinya akan semakin baik dan sebaliknya maka akan menghasilkan kualitas yang rendah dan rentan terhadap hama penyakit. Di daerah penelitian belum menggunakan bibit unggul dan bersertifikat sehingga hasilnya masih jauh dari harapan.

\section{Pupuk kandang}

Variabel pupuk kandang mempunyai koefisien sebesar 0,025 dengan nilai $t_{\text {hitung }}$ sebesar 0,302. Nilai $t_{\text {hitung }}$ lebih kecil dari $t_{\text {tabel }}$ pada taraf $10 \%$ $(1,668)$, dengan demikian variabel pupuk kandang berpengaruh tidak nyata terhadap produksi. Penggunaan pupuk kandang diketahui mampu meningkatkan produksi dan produktivitas tanah secara jangka panjang. Pupuk kandang juga dapat menjadi sarana sekuestrasi karbon ke tanah. Nutrisi pupuk kandang meningkatkan keanekaragaman hayati tanah dengan menyediakan bahan organik dan nutrisi mikro bagi organisme penghuni tanah seperti jamur mikoriza yang membantu tanaman menyerap nutrisi. Namun pada kenyataanya dilapangan variabel pupuk kandang berpengaruh tidak nyata diduga karena pemakaian dosis pupuk kandang di Gapoktan Sarwa Ada belum sesuai anjuran.

\section{Pupuk urea}

Variabel pupuk urea mempunyai koefisien sebesar 0,117 dengan nilai $t_{\text {hitung }}$ sebesar 0,911 . Nilai $t_{\text {hitung }}$ lebih kecil dari $t_{\text {tabel }}$ pada taraf $10 \%(1,668)$, dengan demikian variabel pupuk urea berpengaruh tidak nyata terhadap produksi. Pupuk urea diserap akar tanaman dalam bentuk nitrat atau amonium, yang berpengaruh mempercepat sintesis karbohidrat diubah menjadi protein yang kemudian berfungsi untuk pembentukan biomassa tanaman. Tanaman dengan kandungan $\mathrm{N}$ yang lebih tinggi memiliki daun yang lebih lebar dengan warna daun lebih hijau sehingga fotosintesis berjalan lebih baik. Hasil dari fotosintesis digunakan untuk perkembangan dan pertumbuhan tanaman, antara lain pertambahan ukuran panjang atau tinggi tanaman, pembentukan cabang dan daun baru, yang diekspresikan dalam pembesaran umbi tanaman.

Semakin tinggi fotosintat yang dihasilkan diasumsikan semakin tinggi pula fotosintat yang ditranslokasikan sehingga ukuran umbi akan membesar. Menurut Setyaningrum (2013), pemberian pupuk urea untuk tanaman jahe alangkah baiknya di berikan dengan menguburkannya dalam tanah karena pupuk urea ini mempunyai sifat hogroskopis, dimana pupuk urea mudah menguap jika nanti terkena udara. Namun kenyataan dilapangan pemberian pupuk urea di lakukan dengan menebarkannya di antara barisan tanaman. Pemberian pupuk urea tidak berpengaruh terhadap variabel peningkatan produksi jahe karena teknik pemberiannya kurang tepat.

\section{Pupuk SP-36}

Variabel pupuk SP-36 mempunyai koefisien sebesar 0,023 dengan nilai $t_{\text {hitung }}$ sebesar 0,454 . Nilai $\mathrm{t}_{\text {hitung }}$ lebih kecil dari $\mathrm{t}_{\text {tabel }}$ pada taraf $10 \%$ $(1,668)$, dengan demikian variabel pupuk SP-36 berpengaruh tidak nyata terhadap produksi. Pemberian pupuk SP-36 dapat meningkatkan ketersediaan unsur hara $\mathrm{N}$ yang sangat dibutuhkan untuk pertumbuhan tanaman. Unsur hara $\mathrm{N}$ diperlukan tanaman untuk pembentukan klorofil dan merangsang pertumbuhan tanaman seperti akar, batang, dan daun. Pemberian pupuk dalam tingkat optimum untuk tanaman yang dilakukan 
terus-menerus akan menaikkan kapasitas produktif tanah yang akhirnya dapat menaikkan potensi tanaman yang dihasilkan, hal tersebut dikarenakan pupuk SP-36 mengandung unsur hara N, P, K yang disesuaikan dengan manfaatnya yaitu unsur Nitrogen $(\mathrm{N})$ bermanfaat untuk memicu pertumbuhan secara umum, terutama berperan dalam pembentukan klorofil, asam amino, enzim dan senyawa lain. Tanaman tidak akan memberikan hasil yang maksimal apabila unsur hara yang diperlukan tidak cukup tersedia, pemberian pupuk SP-36 dapat meningkatkan hasil produksi. Namun kenyataan dilapangan petani tidak melakukan pemupukan secara tepat yaitu pada saat musim hujan, padahal pupuk SP-36 dianjurkan penggunaannya pada musim hujan karena pupuk SP-36 cepat larut bila terkena air.

\section{Pupuk KCL}

Variabel pupuk KCL mempunyai koefisien sebesar 0,068 dengan nilai $t_{\text {hitung }}$ sebesar 1,024. Nilai $t_{\text {hitung }}$ lebih kecil dari $t_{\text {tabel }}$ pada taraf $10 \%$ $(1,668)$, dengan demikian variabel pupuk KCL berpengaruh tidak nyata terhadap produksi. Pupuk $\mathrm{KCl}$ berperan dalam meningkatkan aktifitas fotosintesa dan meningkatkan metabolisme karbohidrat serta meningkatkan berat kering tanaman. Sutrisna (2003), menyatakan bahwa keseimbangan unsur hara $\mathrm{K}$ di dalam tanah sangat berperan dalam sintesis karbohidrat dan protein sehingga sangat membantu memperbesar umbi. Kalium mempengaruhi kualitas umbi yaitu menambah keragaman umbi dan meningkatkan bahan kering umbi. Namun pada kenyataanya dilapangan variabel pupuk KCL berpengaruh tidak nyata diduga karena pemakaian dosis pupuk KCL di Gapoktan Sarwa Ada belum sesuai anjuran.

\section{Tenaga kerja}

Variabel tenaga kerja mempunyai koefisien sebesar 0,154 dengan nilai $t_{\text {hitung }}$ sebesar 1,622 Nilai $t_{\text {hitung }}$ lebih kecil dari $t_{\text {tabel }}$ pada taraf $10 \%$ $(1,668)$, dengan demikian variabel tenaga berpengaruh tidak nyata terhadap produksi. Implikasinya adalah jika petani jahe gajah ingin meningkatkan produksi jahe gajah, maka curahan tenaga kerja terutama pemeliharaan tanaman seperti penyiangan untuk membersihkan gulma perlu ditingkatkan dan pembuatan atau perawatan saluran irigasi supaya tidak ada air menggenang dan aliran air tidak melalui petak sehat (sanitasi), sebab keadaan tanaman jahe gajah saat ini banyak terserang hama dan penyakit yang diduga karena lahan sering tergenangi air.

\section{Inefisiensi dan Efisiensi Produksi}

Nilai log likelihood dengan metode maksimum likelihood estimate (MLE) adalah sebesar 46,983 lebih besar dari nilai log likelihood dengan metode OLS yaitu sebesar 34,182 yang berarti fungsi produksi dengan metode MLE sudah baik dan sesuai dengan kondisi di lapangan. Nilai sigmasquare inefisensi sebesar 0,016 yang berarti bahwa error term terdistribusi secara normal. Nilai gamma lebih besar dari 0,01 yaitu sebesar 0,26 menunjukkan bahwa error term hanya berasal dari faktor inefisiensi dan bukan berasal dari noise seperti cuaca, hama dan sebagainya. Pendugaan inefisiensi produksi jahe gajah di Gapoktan Sarwa Ada Desa Taro, Kecamatan Tegallalang, Kabupaten Gianyar tahun 2018 dapat dilihat pada Tabel 3.

Tabel 3. Pendugaan Inefisiensi Produksi dengan Analisis Stochastic Frontier Jahe Gajah

\begin{tabular}{|c|c|c|c|}
\hline Variabel & Koefisien & $\begin{array}{l}\text { Standard- } \\
\text { Error }\end{array}$ & t-ratio \\
\hline Konstanta & $-0,23471$ & 0,28358 & $-0,82766$ \\
\hline $\begin{array}{l}\text { Umur } \\
\text { responden }\end{array}$ & 0,00657 & 0,04108 & 0,16013 \\
\hline $\begin{array}{l}\text { Pendidikan } \\
\text { responden }\end{array}$ & 0,10579 & 0,04297 & $2,46179 * *$ \\
\hline $\begin{array}{l}\text { Pengalaman } \\
\text { bertani }\end{array}$ & 0,02784 & 0,01213 & $2,29479 * *$ \\
\hline $\begin{array}{l}\text { Dummy } \\
\text { penyuluhan }\end{array}$ & $-0,57819$ & 0,18230 & $-3,16053 * * *$ \\
\hline sigma-square & 0,01616 & 0,00521 & 3,10108 \\
\hline Gamma & 0,26556 & 0,38753 & 0,68526 \\
\hline $\begin{array}{l}\text { Log Likelihood } \\
\text { function }\end{array}$ & & 46,98292 & \\
\hline
\end{tabular}

Keterangan:

* = berpengaruh nyata pada taraf $\alpha 10 \%(1,668)$

$* *=$ berpengaruh nyata pada taraf $\alpha 5 \%(1,997)$

$* * *=$ berpengaruh nyata pada taraf $\alpha 1 \%(2,654)$

Pada Tabel 3 dapat diketahui bahwa fungsi inefisiensi teknis dalam penelitian ini digunakan empat variabel yang diduga mempengaruhi inefisiensi produksi jahe gajah. Dari keempat variabel inefisiensi yang diamati, hanya tiga variabel yang berpengaruh nyata yaitu tingkat pendidikan, pengalaman usaha tani dan dummy penyuluhan. Dummy penyuluhan yang berpengaruh nyata pada taraf $\alpha$ sebesar $1 \%$ sedangakan pendidikan petani dan pengalaman berusaha tani berpengaruh nyata pada taraf $\alpha$ sebesar 5\%. Variabel umur responden berpengaruh tidak nyata terhadap inefisiensi.

Variabel umur responden mempunyai koefisien sebesar 0,006 dengan nilai $t_{\text {hitung }} 0,160$, dengan ini berarti nilai $t_{\text {hitung }}$ lebih kecil dari $t_{\text {tabel }}$ pada taraf $10 \%(1,668)$. Hal ini berarti variabel umur petani responden berpengaruh tidak nyata terhadap inefisiensi. Koefisien bernilai positif berarti semakin tua umur petani responden, maka inefisiensi produksi jahe gajah semakin besar dan efisiensinya semakin kecil. Petani yang umurnya semakin tua, maka inefisiensi produksinya akan tinggi. Sebaliknya, petani yang umurnya semakin 
rendah, maka inefisiensi produksi yang dihasilkan akan rendah.

Variabel pendidikan responden mempunyai koefisien sebesar 0,105 dengan nilai $t_{\text {hitung }} 2,461$, dengan ini berarti nilai $t_{\text {hitung }}$ lebih besar dari $t_{\text {tabel }}$ pada taraf $5 \%(1,997)$. Hal ini berarti variabel pendidikan responden berpengaruh nyata terhadap inefisiensi pada taraf 5\%. Nilai koefisiesn positif yang berarti bahwa semakin tinggi tingkat pendidikan petani jahe, maka inefisiensi semakin meningkat dan efisensi akan menurun. Karena tingkat pendidikan petani yang diukur hanya lamanya studi formal atau pengetahuan yang didapat hanya pengetahuan umum bukan pengetahuan tentang usaha tani tanaman jahe gajah.

Variabel pengalaman bertani mempunyai koefisien sebesar 0,027 dengan nilai $t_{\text {hitung }} 2,294$, dengan ini berarti nilai $\mathrm{t}_{\text {hitung }}$ lebih besar dari $\mathrm{t}_{\text {tabel }}$ pada taraf $5 \%(1,997)$. Hal ini berarti variabel pengalaman bertani berpengaruh nyata terhadap inefisiensi pada taraf 5\%. Nilai koefisien positif yang berarti bahwa semakin tinggi tingkat pengalaman petani jahe gajah, maka inefisiensi semakin meningkat dan efisensi akan menurun. Petani jahe gajah di Gapoktan Sarwa Ada Desa Taro tidak mau belajar dari pengalaman yang mereka dapatkan sebelumnya, artinya pada siklus tanam sebelumnya jika hasil produksinya meningkat, maka hal ini seharusnya dipertahankan pada siklus tanam berikutnya.

Variabel dummy penyuluhan mempunyai koefisien sebesar $-0,578$ dengan nilai $t_{\text {hitung }}-3,160$, dengan ini berarti nilai $t_{\text {hitung }}$ lebih besar dari $t_{\text {tabel }}$ pada taraf $1 \%(2,654)$. Hal ini berarti variabel dummy penyuluhan berpengaruh nyata terhadap inefisiensi pada taraf $1 \%$. Nilai koefisiesn negatif yang berarti variabel dummy penyuluhan akan semakin kecil dan efisiensi akan semakin besar. Karena didalam kegiatan penyuluhan petani diberikan informasi dan pemahaman tentang budidaya tanamanan jahe seperti persiapan lahan, pembibitan, penanaman, pemeliharaan, pembibitan, pemanenan, dan penanganan pasca panen, bukan tentang pengetahuan umum seperti pendidikan formal. Dummy penyuluhan diukur berdasarkan partisipasi petani dalam mengikuti penyuluhan di bidang usaha tani jahe gajah.

Efisiensi teknis dianalisis menggunakan model fungsi produksi stochastic frontier dengan metode estimasi Maximum Likelihood Estimate (MLE) dengan program frontier 4.1c sedangkan tingkat efisiensi alokatif dan ekonomi dianalisis dengan menggunakan dual cost frontier. Nilai indeks efisiensi teknis hasil analisis dikategorikan efisien karena menghasilkan nilai yang lebih besar dari 0,70 sebagai batas efisiensi (Coelli, 1998). Hal ini dikarenakan Kecamatan Tegallalang, Kabupaten Gianyar merupakan sentra produksi jahe gajah di Provinsi Bali, sehingga petani jahe gajah di Gapoktan Sarwa Ada Desa Taro mempu menghasilkan efisiensi rata-rata sebesar $91 \%$.
Selain itu usaha tani jahe gajah di Gapoktar Sarwa Ada Desa Taro Kecamatan Tegallalang, Kabupaten Gianyar sudah efisien dan mendekati frontiernya karena berbagai upaya dan program pemerintah banyak dilakukan di daerah ini seperti gencarnya dilakukan penyuluhan tentang budidaya tanaman jahe gajah. Sebaran analisis efisiensi teknis, alokatif dan ekonomis jahe gajah di Gapoktan Sarwa Ada Desa Taro Kecamatan Tegallalang, Kabupaten Gianyar tahun 2018 dapat dilihat pada Tabel 4 .

Tabel 4. Sebaran Efisiensi Teknis, Alokatif dan Ekonomis Jahe Gajah

\begin{tabular}{lccccccc}
\hline & \multirow{7}{*}{$\begin{array}{c}\text { Tingkat } \\
\text { No. }\end{array}$} & \multicolumn{7}{c}{$\begin{array}{c}\text { Jahe } \\
\text { Gajah }\end{array}$} \\
\cline { 3 - 8 } & & TE & $\%$ & AE & $\%$ & EE & $\%$ \\
\hline 1. & $<0,5$ & 0 & 0,00 & 14 & 21,20 & 19 & 28,80 \\
2. & $0,5-0,69$ & 1 & 1,50 & 21 & 31,80 & 26 & 39,40 \\
3. $\quad 0,70-0,90$ & 22 & 33,50 & 21 & 31,80 & 20 & 30,30 \\
$4 . \quad>0,90$ & 43 & 65,00 & 10 & 15,20 & 1 & 1,50 \\
\hline Total & 66 & 100 & 66 & 100 & 66 & 100 \\
Minimum & 0,661 & & 0,206 & & 0,197 & \\
Maksimum & 0,991 & & 0,975 & & 0,911 & \\
Rata-rata & 0,910 & & 0,668 & & 0,599 & \\
\hline
\end{tabular}

Keterangan :

$$
\begin{aligned}
& \mathrm{TE}=\text { Efisiensi Teknis } \\
& \mathrm{AE}=\text { Efisiensi Alokatif } \\
& \mathrm{EE}=\text { Efisiensi Ekonomis }
\end{aligned}
$$

Pada Tabel 4 dapat diketahui bahwa nilai rata-rata efisiensi teknis sebesar 0,910 dengan nilai terendah 0,661 dan nilai tertinggi 0,991 yang berarti usaha tani jahe gajah di Gapokta Sarwa Ada Desa Taro Kecamatan Tegallalang, Kabupaten Gianyar Tahun 2018 secara teknis sudah efisien. Berdasarkan nilai rata-rata efisiensi petani jahe gajah di Gapoktan Sarwa Ada dapat dikemukakan bahwa petani jahe gajah masih mempunyai peluang untuk memperoleh hasil yang maksimal dengan penggunaan input produksi secara efisien. Hasil ini menunjukkan bahwa secara keseluruhan petani dapat meningkatkan produksinya apabila penggunaan input produksi ditingkatkan sebesar 9\% (1-0,910). Tetapi masih banyak faktor lain (vi) yaitu faktor yang tidak dapat dikendalikan yang perlu diperhatikan oleh petani jahe gajah di Gapoktan Sarwa Ada seperti hama, penyakit, iklim, dan sistem drainase dikarenakan nilai gamma yang kecil $(26,55 \%)$.

Efisiensi alokatif dan ekonomis diperoleh melalui analisis dengan memperhitungkan rasio harga input dengan harga output. Usaha tani jahe gajah di Gapoktan Sarwa Ada Desa Taro, Kecamatan Tegallalang, Kabupaten Gianyar memiliki nilai rata-rata efisiensi alokatif sebesar 0,668 dengan nilai terendah sebesar 0,206 dan nilai tertinggi 
sebesar 0,975. Jika rata-rata petani jahe gajah di Gapoktan Sarwa Ada dapat mencapai efisiensi alokatif yang paling tinggi, maka mereka dapat menghemat biaya sebesar 31,49\% (1 $(0,668 / 0,975))$. Penggunaan input yang kurang atau berlebihan menyebabkan rendahnya efisiesnsi alokatif, selain itu rendahnya efisiensi alokatif juga disebabkan oleh belum adanya informasi harga input maupun output secara jelas, sehingga keragaman harga input dan output tidak cukup digambarkan oleh harga rata-rata. Jika harga output transparan dan petani jahe gajah dapat menikmati harga murah (kebijakan subsidi input), maka petani jahe gajah dapat menikmati efisiensi alokatif, sehingga akan menghemat biaya produksi dan akhirnya akan dapat meningkatkan pendapatan.

Nilai rata-rata efisiensi ekonomis pada usaha tani jahe gajah di Gapoktan Sarwa Ada Desa Taro, Kecamatan Tegallalang, Kabupaten Gianyar sebesar 0,599 dengan nilai tertinggi sebesar 0,911 dan nilai terendah sebesar 0,197. Hal ini menunjukkan apabila rata-rata petani jahe gajah dapat mencapai efisiensi ekonomis tertinggi maka petani dapat merealisasikan dengan menghemat input produksi sebesar 34,25\% (1-(0,599/0,911)).

Efek gabungan dari efisiensi teknis dan efisiensi alokatif menunjukkan bahwa rata-rata efisiensi ekonomis usaha tani jahe gajah sebesar 0,599. Artinya usaha tani jahe gajah di Gapoktan Sarwa Ada Desa Taro, Kecamatan Tegallalang, Kabupaten Gianyar belum efisien secara ekonomi. Penyebab rendahnya efisiensi ekonomis karena efisiensi alokatif yang masih rendah. Sementara efisiensi teknis sudah relatif tinggi. Usaha tani jahe gajah di Gapoktan Sarwa Ada Desa Taro, Kecamatan Tegallalang, Kabupaten Gianyar masih perlu meningkatkan efisiensi ekonomis sebesar $34,25 \%$. Belum efisiennya efisiensi alokatif yang kemudian menyebabkan rendahnya efisiensi ekonomis, menunjukkan bahwa usaha tani jahe gajah di Gapoktan Sarwa Ada Desa Taro, Kecamatan Tegallalang, Kabupaten Gianyar belum mampu memperoleh pendapatan yang maksimum.

Sebaran tingkat (rating) efisiensi teknis, alokatif dan ekonomis disajikan pada Tabel 5.14 dapat diperoleh keterangan bahwa petani jahe gajah yang efisien secara teknis sebanyak 65 orang (98,5\%), petani jahe gajah yang efisien secara alokatif sebanyak 31 orang $(47 \%)$, dan petani jahe gajah yang efisien secara ekonomis sebanyak 21 orang $(31,80 \%)$.

\section{Pendapatan Usaha Tani}

Penerimaan adalah sejumlah uang yang diterima oleh perusahaan atas penjualan produk yang dihasilkan. Dalam ilmu ekonomi penerimaan diistilahkan revenue. Dalam penelitian ini penerimaan diperoleh dari hasil produksi jahe gajah dikalikan harga jahe gajah. Produksi merupakan suatu kegiatan yang dikerjakan untuk menambah nilai guna suatu benda atau menciptakan benda baru sehingga lebih bermanfaat dalam memenuhi kebutuhan. Kegiatan menambah daya guna suatu benda tanpa mengubah bentuknya dinamakan produksi jasa. Kegiatan menambah daya guna suatu benda dengan mengubah sifat dan bentuknya dinamakan produksi barang. Dalam usaha tani ini, produksi yang dimaksud adalah menciptakan produk baru yaitu jahe gajah. Produksi yang dihasilkan oleh petani jahe gajah di Gapoktan Sarwa Ada Desa Taro sejumlah $227.420 \mathrm{~kg}$ per siklus tanam.

Rata-rata harga jual jahe gajah di tingkat petani pada satu kali musim panen sebesar Rp 5.007,58 per kg. Hal yang sama terjadi pada penerimaan usaha tani jahe gajah, dimana kuantitas jahe gajah yang dihasilkan dan harga jahe gajah per kilogramnya sangat menentukan besarnya penerimaan dari usaha tani ini. Penerimaan usaha tani jahe gajah diperoleh dari kuantitas produk jahe gajah dikalikan dengan harga per kilogram jahe gajah. Pada usaha tani jahe gajah di Gapoktan Sarwa Ada Desa Taro Kecamatan Tegallalang, Kabupaten Gianyar dengan luas lahan secara keseluruhan seluas 28,51 ha memperoleh total penerimaan sebesar Rp $1.139819 .500,00$ per siklus tanam. Produksi jahe dalam penelitian ini berupa umbi basah (dalam keadaan segar) dengan rata-rata produksi jahe gajah sebesar $3.445,76 \mathrm{~kg}$ per siklus tanam.

Rata-rata biaya tetap sebesar Rp 230.668,56 per siklus tanam yang diperoleh dari biaya penyusutan peralatan ditambah biaya pajak. Rata-rata biaya variabel sebesar Rp 9.946.325,00 per siklus tanam yang diperoleh dari biaya tenaga kerja ditambah biaya pupuk (pupuk kandang, urea, SP-36, KCL) dan ditambah biaya bibit. Rata-rata biaya merupakan hasil dari rata-rata biaya tetap ditambah rata-rata biaya variabel yang memperoleh hasil sebesar Rp 10.145.498,21 per siklus tanam. Rata-rata penerimaan, biaya, dan pendapatan usaha tani jahe gajah dilihat pada Tabel 5.

Pada Tabel 5 dapat diketahui bahwa petani jahe gajah di Gapoktan Sarwa ada Desa Taro Kecamatan Tagallalang Kabupaten Gianyar, memperoleh pendapatan bersih usaha tani jahe gajah adalah $\mathrm{Rp} 7.124 .494,21$ per luas lahan garapan $(0,43$ ha) per siklus tanam. Pendapatan dalam usaha tani dianalisis melalui penerimaan total biaya. Dapat disimpulkan bahwa usaha tani jahe gajah di Gapoktan Sarwa Ada Desa Taro Kecamatan Tagallalang Kabupaten Gianyar, sudah mengalami keuntungan dilihat dari nilai $\mathrm{R} / \mathrm{C}$ ratio sebesar 1,7, yang berarti bahawa, setiap biaya yang dikeluarkan sebesar Rp. 1.000,00 akan mendapat penerimaan sebesar Rp. 1.700,00. Sehingga dapat dikatakan bahwa usaha tani jahe gajah di Gapoktan Sarwa Ada Desa Taro Kecamatan Tagallalang Kabupaten Gianyar layak untuk diusahakan atau dikembangkan karena nilai net $\mathrm{B} / \mathrm{C}$ ratio lebih besar dari satu 
Tabel 5. Rata-rata penerimaan, biaya, dan pendapatan usaha tani jahe gajah

\begin{tabular}{|c|c|c|c|c|}
\hline No & Uraian & Jumlah & $\begin{array}{c}\text { Harga } \\
(\mathrm{Rp})\end{array}$ & Total (Rp) \\
\hline I & Produksi (kg) & $3.445,76$ & $5.007,58$ & $17.269 .992,42$ \\
\hline \multirow{8}{*}{. } & Biaya Variabel & & & \\
\hline & Tenaga Kerja (HOK) & 56,04 & $49.545,50$ & $2.808 .011,37$ \\
\hline & Pupuk Kandang (kg) & $4.351,52$ & $1.142,42$ & $4.981 .136,36$ \\
\hline & Urea $(\mathrm{kg})$ & 255,88 & $1.219,70$ & $313.007,57$ \\
\hline & SP-36 (kg) & 124,94 & $5.245,45$ & $655.368,18$ \\
\hline & $\mathrm{KCL}(\mathrm{kg})$ & 43,30 & $2.640,91$ & $114.293,94$ \\
\hline & Bibit & 89.44 & $12.083,30$ & 1.074.507,58 \\
\hline & Total Biaya Variabel & & & $9.946 .325,00$ \\
\hline \multirow{6}{*}{$\begin{array}{r}\text { III } \\
1 \\
1 \\
2 \\
3 \\
4\end{array}$} & Biaya tetap & & & \\
\hline & Sabit (buah) & 3,54 & $45.659,10$ & $53.901,51$ \\
\hline & Cangkul (buah) & 2,97 & $78.166,70$ & $5.7948,80$ \\
\hline & Keranjang (buah) & 3,24 & $64.848,50$ & $32.424,24$ \\
\hline & Pajak & 43,20 & 2000,00 & $86.393,94$ \\
\hline & Total Biaya Tetap & & & $230.668,56$ \\
\hline IV & Total Biaya Produksi & & & $10.145 .498,21$ \\
\hline V & Penerimaan & & & $17.269 .992,42$ \\
\hline VI & Pendapatan & & & 7.124.494,21 \\
\hline VI & R/C Ratio & & & 1,7 \\
\hline
\end{tabular}

\section{Kendala-kendala usaha tani jahe gajah}

Kendala-kendala yang dihadapi petani dalam usaha tani jahe gajah di Gapoktan Sarwa Ada Desa Taro, Kecamatan Tegallalang Kabupaten Gianyar adalah belum ada standar harga jahe gajah, belum ada akses pasar secara tetap dan serangan penyakit busuk rimpang. Kendala petani jahe gajah di Gapoktan Sarwa Ada Desa Taro, Kecamatan Tegallalang, Kabupaten gianyar dapat dilihat pada Tabel 6 .

Tabel 6. Frekuensi kendala.

\begin{tabular}{llcc}
\hline Aspek & \multicolumn{1}{c}{ Kendala } & $\begin{array}{l}\text { Jumlah } \\
\text { (orang) }\end{array}$ & $(\%)$ \\
\hline Ekonomis & $\begin{array}{l}\text { Belum Ada Standar } \\
\text { Harga Jahe Gajah }\end{array}$ & 42 & 63,6 \\
& Akses Pasar & 56 & 84,8 \\
Teknis & $\begin{array}{l}\text { Penyakit Busuk } \\
\text { Rimpang }\end{array}$ & 31 & 46,9 \\
\hline
\end{tabular}

Pada Tabel 6 dapat diketahui bahwa kendala yang paling dominan dihadapi oleh petani jahe gajah adalah akses pasar sebesar 56 orang $(84,8 \%)$, diikuti belum ada standar harga jahe gajah sebesar 42 orang $(63,6 \%)$, dan kendala penyakit busuk rimpang sebesar 31 orang (46\%). Kendala akses pasar perlu mendapatkan perhatian yang serius, karena sebagian besar petani jahe gajah belum memiliki akses pasar yang luas. Petani menjualkan jahe gajah yang diproduksi hanya kepada tengkulak-tengkulak yang berada Desa Taro. Petani belum memiliki informasi pasar yang memadai mengenai pasar jahe gajah, sehingga mayoritas petani belum mengetahui nilai ekonomi dan potensi keuntungan yang dimiliki secara pasti. Hal ini yang membuat usaha tani jahe gajah di Gapoktan Sarwa Ada Desa Taro, Kecamatan Tegallalang, Kabupaten Gianyar belum maksimal dan sebagian besar petani dalam pembudidayaan jahe gajah belum dalam skala besar. Kendalakendala usaha tani jahe gajah di Gapoktan Sarwa Ada dapat dilihat sebagai berikut.

\section{Belum ada standar harga jahe gajah}

Saat ini Jahe Gajah belum memiliki standar harga. Harga jahe gajah yang ada di Gapoktan Sarwa Ada Desa Taro, Kecamatan Tegallalang, Kabupaten Gianyar, saat ini masih dikendalikan oleh tengkulak. Belum ada HPP (harga patokan petani) untuk komoditi jahe gajah. Petani kurang mengetahui mengenai informasi harga jual jahe gajah yang ada di pasaran. Petani hanya mendapatkan informasi harga dari tengkulak. Petani jahe gajah memasarkan hasil produksi jahe gajah yang dimiliki hanya kepada tengkulak. Hal ini mengakibatkat informasi pasar yang petani dapatkan sangat terbatas. Akibatnya tengkulak menjadi pihak yang diuntungan, karena tengkulak yang menentukan harga jual jahe gajah untuk petani.

Harga yang dikendalikan oleh tengkulak berdampak pada semakin sedikitnya minat petani untuk mengusahakan jahe gajah karena takut mengalami kerugian. Hal ini sangat penting untuk menjadi perhatian khusus oleh pemerintah untuk menentukan standar harga jual jahe gajah. Mengingat jahe gajah merupakan komoditas ekspor yang memiliki prospek pasar yang bagus di mancanegara, sangat disayangkan apabila hal ini menghambat pengembangan usaha tani jahe gajah di Bali, khususnya di Gapoktan Sarwa Ada Desa Taro, Kecamatan Tegallalang, Kabupaten Gianyar.

\section{Akses pasar}

Lemahnya akses pasar petani jahe gajah selama ini disebabkan beberapa hal, diantaranya: (1) kesulitan mencari pembeli dalam jumlah besar; (2) biaya operasional untuk sampai ke konsumen dirasakan petani jahe gajah cukup tinggi, sehingga muncul keengganan untuk mengakses pasar sendiri; (3) petani jahe gajah kurang termotivasi meningkatkan usaha mereka. Karena petani jahe gajah berpikir yang penting usahanya jalan; (4) lemahnya upaya pemasaran, baik dari petani jahe gajah maupun dari bantuan pemerintah.

Beberapa upaya prakondisi yang harus dilakukan dalam upaya penguatan akses pasar, antara lain: (1) pemerintah melakukan sosialisasi memberikan 
kesadaran petani jahe gajah yang mereka usahakan sehingga berdampak terhadap kesuksesan produk yang mereka hasilkan; dan (2) standarisasi kualitas. Hal ini penting dilakukan agar tercipta kontinyuitas permintaan pasar. Seringkali petani jahe gajah rentan terhadap penurunan kualitas jika terjadi peningkatan permintaan. Adanya standarisasi kualitas juga memberikan kesadaran pada petani jahe gajah bahwa produk yang berkualitas akan dapat menjamin kelangsungan usaha tani yang mereka kelola. Dampak standarisasi kualitas berpotensi petani jahe gajah mengadopsi teknologi yang mampu melakukan proses produksi dengan lebih cepat, akurat dan lebih terukur.

Pada tahapan selanjutnya, adalah tahap analisis potensi dan peluang, dimana petani jahe gajah dapat melakukan pemetaan potensi pasar. Hal ini sangat dibutuhkan petani mengingat lemahnya informasi tentang pasar. Nilai manfaat pemetaan itu adalah produk yang mereka hasilkan dapat segera dipasarkan dan dapat diperhitungkan jalur transportasi yang digunakan dalam penentuan harga jual jahe gajah.

Ketika pemetaan pasar sudah dilakukan, petani jahe gajah dapat meningkatkan akses pasar. Beberapa langkah alternatif peningkatan akses pasar dapat dilakukan antara lain adalah (1) melakukan pelatihan peningkatan akses pasar. Petani jahe gajah perlu mendapat pelatihan tentang akses pasar, sehingga mereka memahami arti penting menjaga kualitas produk, yang akan meningkatkan permintaan hasil produksi. Pelatihan ini juga bertujuan agar petani jahe gajah mengetahui prosedur, bernegoisasi harga, ataupun menjual produk ke pasar sasaran; (2) meningkatkan networking atau jaringan pemasaran baru melalui pameran, baik lokal maupun keluar daerah. Promosi ini penting dilakukan untuk mendekatkan hasil produksi petani pada kebutuhan pasar; (3) Petani jahe gajah harus aktif mencari peluang-peluang pasar. Peluang-peluang pasar dapat dicari dengan melakukan kemitraan dengan perusahaan-perusahaan yang memasok jahe gajah, mencari supplyer yang mendistribusikan jahe gajah ke pasar yang lebih luas atau distributor ekspor, dan memasarkan produknya media cetak maupun media online sehingga tidak bergantung kepada tengkulak. Meningkatkan jangkauan pasar akan semakin membuka peluang usaha budidaya jahe gajah di Gapoktan Sarwa Ada Desa Taro, Kecamatan Tegallalang, Kabupaten Gianyar. Petani juga akan mendapat keuntungan yang lebih besar dengan jangkauan pemasaran jahe gajah yang lebih luas.

\section{Penyakit Busuk Rimpang}

Kendala yang dialami petani jahe gajah di Gapoktan Sarwa Ada Desa Taro, Kecamatan Tegallalang, Kabupaten Gianyar adalah penyakit busuk rimpang. Gejala awal penyakit ditandai dengan menguningnya pinggiran daun dari daun terbawah, yang secara perlahan seluruh daun akan menguning dan akhirnya seluruh tanaman menguning. Daun-daun tertua akan mengering, diikuti dengan daun-daun yang lebih muda dan akhirnya batang juga akan mengering. Batang yang mengering masih kuat sehingga sulit dicabut dari rimpangnya.

Penyebab penyakit busuk rimpang adalah jamur fusarium merupakan jamur tular tanah, bertahan dalam tanah yang menyerang rimpang jahe gajah (klamidospora). Selain terinfeksi oleh jamur yang berada dalam tanah, tanaman dapat juga menjadi sakit karena jamur yang terbawa bibit tanaman yang diambil dari tanaman sakit. Sumber penularan utama pada pertanaman jahe adalah penanaman rimpang sakit. Jamur berkembang baik pada keadaan suhu panas $\left(15-38^{\circ} \mathrm{C}\right)$, udara lembab $(87-95 \%)$ dan keadaan tanah basah atau becek yang lama karena drainase yang buruk.

Meluasnya penyakit busuk rimpang di Gapoktan Sarwa Ada Desa Taro, Kecamatan Tegallalang, Kabupaten Gianyar mengindikasikan bahwa umumnya tanah pertanian dan benih rimpang jahe yang digunakan oleh para petani sebagian besar sudah tercemar atau terinfeksi oleh jamur Fasarium Oxysporum penyebab penyakit busuk rimpang, sehingga tanah dan rimpang sehat untuk tujuan produksi jumlahnya sangat terbatas. Untuk menghentikan penyebaran penyakit busuk rimpang agar tidak lebih meluas, ada beberapa langkah tindakan pencegahan maupun pengendalian.

Pertama perlakuan benih sebelum tanam, metode perlakuan benih ini dapat digunakan petani dalam usaha pemenuhan bibit sendiri. Keuntungan petani membibitkan jahe sendiri adalah: a) petani akan mengetahui kondisi bibit yang akan ditanam; b) penyediaan bibit tidak terbatas; c) efisiensi biaya pembelian bibit; dan d) bibit terjamin. Secara teknis, tanaman induk untuk bibit dapat ditanam di polybag. Penggunaan polybag mudahkan dalam penyortiran tanaman yang sehat dan pencegahan penularan penyakit ke tanaman lain dapat dilakukan.

Kedua sterilisasi tanah sebelum tanam, untuk penyakit-penyakit tanaman yang disebabkan oleh jamur tular tanah seperti halnya jamur Fusarium, sterilisasi tanah sangat dianjurkan untuk menekan propagul jamur dalam tanah dan jumlah tanaman yang terinfeksi penyakit busuk rimpang. Salah satu metoda untuk sterilisasi tanah adalah solarisasi tanah pada saat musim panas.

Solarisasi tanah dilakukan dengan tahap-tahap sebagai berikut; a) pengolahan tanah dengan membalik tanah; b) membasahi tanah; c) penutupan tanah dengan mulsa plastik (polyethylene) yang transparan (tembus cahaya) yang dibiarkan selama kurang lebih 4 - 8 minggu; 3) Intercropping, intercropping jahe dengan Capsicum (cabai) dapat mengendalikan penyakit sebesar 75\%: 4) Pengendalian penyakit di lapang, penggunaan fungisida seperti mancozeb, benomyl, metil tiofanat dan karbendazim dapat digunakan untuk pengendalian penyakit busuk rimpang di 
lapang dengan cara menyiramkan fungisida ke tanah dekat perakaran secara teratur satu sampai dengan dua kali setiap 15 hari; dan 5) Karantina, tindakan karantina secara ketat perlu dilakukan terhadap masuknya benih rimpang yang berasal dari kebun atau daerah yang terinfeksi penyakit ke kebun atau daerah baru yang belum terinfeksi. Tindakan-tindakan pencegahan seperti sortir ketat rimpang-rimpang jahe untuk bahan tanaman, solarisasi tanah, perlu diaplikasikan pada daerahdaerah yang belum terserang penyakit.

\section{Uji Hipotesis}

Berdasarkan hasil pengujian di atas dapat disimpulkan bahwa $\mathrm{H}_{1}$ di terima. Hipotesis faktorfaktor produksi berpengaruh positif terhadap produksi jahe gajah. Hal ini dilihat dari variabel luas lahan berpengaruh nyata pada taraf $1 \%$ dan variabel bibit, pupuk kandang, urea, SP-36, KCL dan tenaga kerja berpengaruh positif terhadap produksi. Menurut Soekartawi (2005), dalam meningkatkan hasil produksi pertanian dan pertumbuhan tanaman yang baik perlu memperhatikan penggunaan faktor-faktor produksi.

Berdasarkan hasil pengujian di atas dapat disimpulkan bahwa $\mathrm{H}_{2}$ diterima. Penggunaan input produksi jahe gajah di Gapoktan Sarwa Ada Desa Taro Kecamatan Tegallalang, Kabupaten Gianyar dinyatakan efisien secara teknis karena nilai ratarata efisiensinya sebesar 0,910 lebih besar dari 0,700. Hal ini sejalan dengan penelitian Kurniwan (2012), bahwa penggunaan input secara tepat akan berpengaruh terhadap efisiensi produksi.

Berdasarkan hasil pengujian di atas dapat disimpulkan bahwa $\mathrm{H}_{3}$ ditolak. Penggunaan input produksi jahe gajah di Gapoktan Sarwa Ada Desa Taro Kecamatan Tegallalang, Kabupaten Gianyar dinyatakan belum efisien secara alokatif, karena nilai rata-rata efisiensinya sebesar 0,668 lebih kecil dari 0,700 . Tidak efisien usaha tani secara alokatif disebabkan oleh belum adanya informasi harga input maupun output secara jelas (Kune, 2016).

Berdasarkan hasil pengujian di atas dapat disimpulkan bahwa $\mathrm{H}_{4}$ ditolak. Penggunaan input produksi jahe gajah di Gapoktan Sarwa Ada Desa Taro Kecamatan Tegallalang, Kabupaten Gianyar dinyatakan belum efisien secara ekonomis, karena nilai rata-rata efisiensinya sebesar 0,599 lebih kecil dari 0,700. Penyebab rendahnya efisiensi ekonomis karena efisiensi alokatif yang masih rendah, sementara efisiensi teknis sudah relatif tinggi (Chonani, 2014)

\section{SIMPULAN DAN SARAN}

\section{Simpulan}

Variabel luas lahan berpengaruh nyata terhadap produksi pada taraf $1 \%$, sedangkan variabel bibit, pupuk kandang, urea, SP-36, KCL, dan tenaga kerja berpengaruh tidak nyata terhadap produksi. Variabel pendidikan responden dan pengalaman bertani berpengaruh nyata pada taraf 5\% sedangkan variabel dummy penyuluhan berpengaruh nyata pada taraf $1 \%$ dengan koefisien bernilai negatif. Usaha tani jahe gajah dinyatakan efisien secara teknis dengan nilai rata-rata sebesar 0,910 sedangkan belum efisien secara alokatif dengan nilai rata-rata sebesar 0,668 dan belum efisien secara ekonomis dengan nilai rata-rata sebesar 0,599. Usaha tani jahe gajah di Gapoktan Sarwa Ada Desa Taro Kecamatan Tagallalang Kabupaten Gianyar, sudah mengalami keuntungan dilihat dari nilai $\mathrm{R} / \mathrm{C}$ ratio sebesar 1,7 , sehingga dapat dikatakan bahwa usaha tani jahe gajah di Gapoktan Sarwa Ada Desa Taro Kecamatan Tagallalang Kabupaten Gianyar layak untuk diusahakan atau dikembangkan karena nilai net $\mathrm{R} / \mathrm{C}$ ratio lebih besar dari satu. Kendala-kendala yang dihadapi dalam usaha tani jahe gajah di Gapoktan Sarwa Ada Desa Taro Kecamatan Tagallalang Kabupaten Gianyar adalah belum adanya standar harga yang ditetapkan, sulitnya mendapat akses pasar, dan penyakit busuk rimpang.

\section{Saran}

Peningkatan produksi dapat dilakukan dengan mengoptimalkan penggunaan lahan pada satu areal tanam dengan pola monokultur dan pengaturan jarak tanam yaitu $60 \times 40 \mathrm{~cm}$. Perlu adanya peran serta penyuluh pertanian dalam upaya memberikan pemahaman mengenai teknis dalam kegiatan produksi, budidaya, maupun pemasaran. Peningkatan produksi jahe gajah harus ditunjang dengan adanya perluasan pasar (ekspansi pasar) dan perlu adanya peran serta pemerintah dalam menjaga stabilitas harga. Sebelum melakukan penanaman petani perlu mensortir ketat rimpangrimpang jahe untuk bahan tanaman dan solarisasi tanah untuk mencegah penyakit busuk rimpang.

\section{Daftar Pustaka}

Chonani, S. H., F. E. Prasmatiwi, dan H. Santoso. 2014. "Efisiensi Produksi dan Pendapatan Usaha tani Cabai Merah di Kecamatan Metro Kibang Kabupaten Lampung Timur: Pendekatan Fungsi Produksi Frontier". Lampung: Universitas Lampung. Jurnal Agrotek Tropika. No 1, Vol 2, Hal 89-94.

Coelli, T., D. S. P. Rao and G. E. Battese. 1998. An Introduction to Efficiency and Productivity Analysis. Kluwer Academic Publishers, Boston.

Falloa. Dkk. 2018. Faktor-Faktor yang Mempengaruhi Produksi Padi Sawah di Kecamatan Biboki Moenleu Kabupaten Timor Tengah Utara Provinsi Nusa Tenggara Timur. Jurnal Agrimor. Vol. 3, No. 4, Hal. 64-66. 
Kementrian Pertanian. 2015. Outlook Komoditi Jahe. Pusat Data dan Sistem Informasi Pertanian Sekretariat Jendral-Kementrian Pertanian. Jakarta: Kementrian Pertaninan.

Kune. 2016. Analisis Efisiensi Teknis Dan Alokatif Usaha tani Jagung (Studi Kasus Di Desa Bitefa Kecamatan Miomafo Timur Kabupaten Timor Tengah Utara). Jurnal Agromor. Vol. 1, No. 1, Hal. 3-6.

Kurniawan, A. Y., 2012. Efisiensi Teknis pada Usaha tani Padi Lahan Pasang Surut di Kecamatan Anjir Muara Kabupaten Barito Kuala Kalimantan Selatan. Jurnal Agribisnis Pedesaan. Vol. 2, No. 1, Hal. 35-52.

Lana, M., dan Kune, S. J. 2016. Faktor-Faktor yang Mempengaruhi Produksi Usaha Tani Sayur Sawi di Kelurahan Bensone Kecamatan Kota Kefamenanu Kabupaten Timor Tengah Utara. Jurnal Agrimor. Vol. 1, No. 2, Hal. 27-29.

Mantra, I. B. dan Kasto. 1987. Penentuan Sampel. Dalam Singarimbun, Masri dan Sofian Effendi (Editor) 1989. Jakarta: Metode Penelitian Survai LP3ES.

Misgiantoro, R., Prasmatiwi, F. E, dan Nurmayasari, I., 2017. Analisis Efisiensi
Produksi Dan Pendapatan Usaha tani Jahe Di Kecamatan Penengahan Kabupaten Lampung Selatan. Jurnal IIIa. Vol. 5, No. 1, Hal. 22-30.

Nicholson, W. 1995. Teori Mikroekonomi. Binarupa Aksara. Jakarta.

Purnami, E., Khaswarina, S., dan Tarumun S., 2012. Pengaruh Faktor-Faktor Produksi Terhadap Produksi Sawi di Kelurahan Maharatu Kecamatan Marpoyan Damai Kota Pekanbaru. Jurnal IJAE. Vol. 3, No. 1, Hal. 13-36.

Setyaningrum dan Saparinto. 2013. Jahe. Jakarta: Penebar Swadaya

Soekartawi. 2005. Analisis Usaha tani. Jakarta: UI Press.

Sugiyono. 2014. Metode Penelitian Pendidikan Pendekatan Kuantitatif, Kualitatif Dan R\&D. Bandung: Alfabeta. 